\title{
Molecular Docking Analysis of Ginger Active Compound on Transient Receptor Potential Cation Channel Subfamily V Member 1 (TRPV1)
}

\author{
Fifteen Aprila Fajrin ${ }^{1,2}$, Agung Endro Nugroho², Arief Nurrochmad ${ }^{2,}$, and Rina Susilowati ${ }^{3}$ \\ ${ }^{1}$ Faculty of Pharmacy, University of Jember, Jl. Kalimantan I/2, Jember 68121, Indonesia \\ ${ }^{2}$ Faculty of Pharmacy, Universitas of Gadjah Mada, Sekip Utara, Yogyakarta 55281, Indonesia
}

${ }^{3}$ Faculty of Medicine, Universitas of Gadjah Mada, Jl. Farmako, Sekip Utara, Yogyakarta 55281, Indonesia

Received September 9, 2017; Accepted October 27, 2017

\begin{abstract}
Ginger had been reported to ameliorate Painful Diabetic Neuropathy (PDN) in an animal model. Gingerol and shogaol were active compounds of ginger that potentially act on transient receptor potential cation channel subfamily $V$ member 1 (TRPV1), a key receptor in PDN. This study aims to predict the binding of gingerol and shogaol to TRPV1 using an in silico model. The ligands of the docking study were 3 chemical compounds of each gingerol and shogaol, i.e. 6-shogaol, 8-shogaol, 10-shogaol, 6-gingerol, 8 gingerol and 10-gingerol. Capsaicin, a TRPV1 agonist, was used as a native ligand. The TRPV1 structure was taken from Protein Data Bank (ID 3J9J). The docking analysis was performed using Autodock Vina. The result showed that among the ginger active compounds, 6shogaol had the strongest binding energy $(-7.10 \mathrm{kcal} / \mathrm{mol})$ to TRPV1. The 6-shogaol lacked the potential hydrogen bond to Ile265 of TRPV1 protein, which capsacin had. However, it's binding energy towards TRPV1 was not significantly different compared to capsaicin. Therefore, 6-shogaol had potential to be developed as a treatment for PDN.
\end{abstract}

Keywords: gingerol; shogaol; diabetes mellitus; painful diabetic neuropathy; TRPV1

\section{ABSTRAK}

Jahe dilaporkan mempunyai aktivitas memperbaiki Nyeri Neuropati Diabetes (NND) pada hewan model. Gingerol dan shogaol merupakan senyawa aktif jahe yang potensial. Penelitian ini bertujuan untuk memprediksi aktivitas gingerol dan shogaol pada Transient Receptor Potential Cation Channel Subfamily V Member 1 (TRPV1) reseptor target pada NND, menggunakan model in silico. Ligan yang digunakan pada penelitian ini adalah tiga senyawa dari masing-masing turunan gingerol dan shogaol, yaitu 6-shogaol, 8-shogaol, 10-shogaol, 6-gingerol, 8gingerol dan 10-gingerol. Capsaisin, merupakan agonis TRPV1 yang digunakan sebagai native ligand pada penelitian ini. TRPV1 diperoleh dari protein data bank (PDB) dengan ID. 3J9J. Prediksi ikatan ligan terhadap reseptor dilakukan menggunakan Autodock Vina. Hasil penelitian ini menunjukkan bahwa diantara komponen aktif jahe, 6-shogaol memberikan energi ikatan yang paling kuat terhadap TRPV1 (-7,10 kkal/mol). Senyawa 6-shogaol tidak mempunyai ikatan hidrogen pada posisi lle265 terhadap TRPV1 seperti yang dimiliki capsaisin, namun mempunyai energi ikatan yang tidak berbeda bermakna dengan capsaisin terhadap TRPV1. Hasil ini menunjukkan bahwa 6-shogaol dapat dikembangkan lebih lanjut sebagai terapi untuk NND.

Kata Kunci: gingerol; shogaol; diabetes melitus; nyeri neuropati diabetes; TRPV1

\section{INTRODUCTION}

Painful Diabetic Neuropathy (PDN) is one of the complications of long-term Diabetes Mellitus (DM) [1]. PDN affects $15-20 \%$ of diabetic patients and $50 \%$ of diabetic patients with peripheral neuropathy [2]. International Diabetes Federation (IDF) reveals that there are 371 million diabetes mellitus patients in the world in 2012 [3]. Indonesia is at $9^{\text {th }}$ position among countries with the highest diabetes incidence in 2010 and is predicted to be at a $6^{\text {th }}$ position in 2030 [4]. The increasing number of diabetic patients leads eventually to increasing patients with PDN.

Treatment for PDN is still a challenge, related to the complexity of the pathophysiology and the adverse effect of drugs that are widely used for PDN. Many patients do not achieve a good result and suffered from adverse effects when they receive first-line treatment such as tricyclic antidepressant (TCA) or gammaaminobutyric acid (GABA) agonist [5]. Therefore, development of molecular targeted drugs for PDN treatment, are needed.

* Corresponding author

Email address : ariefnr@ugm.ac.id 
One of the new target molecules for PDN drug is Transient Receptor Potential Cation Channel Subfamily V Member 1 (TRPV1). Brito et al. [6] reported higher activity of TRPV1 in animals with PDN. Long-term hyperglycemia leads to increase production of reactive oxygen species (ROS) that activates TRPV1 [7]. Activation of TRPV1 causes depolarization and leads to stimulation of $\mathrm{N}$-methyl D-aspartate (NMDA) receptor. The activation of NMDA receptor induces pain sensitization that is characterized by hyperalgesia and allodynia [8-9].

Inhibition of TRPV1 activity prevents pain propagation in dorsal root ganglia (DRG), spinal cord and brain; hence reduce pain sensitization [7]. One of the drugs that inhibit TRPV1 and had been developed to reduce PDN is capsaicin [10]. Capsaicin is one of the active ingredients of chili that have a burning sensation. Therefore, its development for oral and topical administered drug is problematic. This reason makes capsaicin not commonly chosen as oral treatment for PDN.

Zingiber officinale, also known as ginger, is widely used as a component of foods or beverages. Gingerol and shogaol were discovered as the active compounds of ginger that have responsibility for its pharmacological action [11]. Gingerol and shogaol have a similar structure with capsaicin and have been identified as TRPV1 agonist, as well [11-12]. Therefore, gingerol and shogaol are potential candidates to be developed as PDN drug. In this study, the binding prediction of several forms of gingerol and shogaol to TRPV1 are analyzed using docking analysis in an insilico model. The prediction of binding energy of gingerol and shogaol to TRPV1 will be compared to the binding energy of capsaicin. The data is needed to choose the most promising ginger's active compound to be developed as a drug for PDN.<smiles>COc1cc(C(C)(C)NC(=O)CC(C)(C)CCC=CC(C)C)ccc1O</smiles>

(a)<smiles>CCCCCCCCC=CC(=O)CCc1ccc(O)c(OC)c1</smiles><smiles>CCCCCCCCC/C=C/C(=O)CCc1ccc(O)c(OC)c1</smiles><smiles>CCCCCC(O)CC(=O)CCc1ccc(O)c(OC)c1</smiles><smiles>CCCCCCCC(O)CC(=O)CCc1ccc(O)c(OC)c1</smiles>

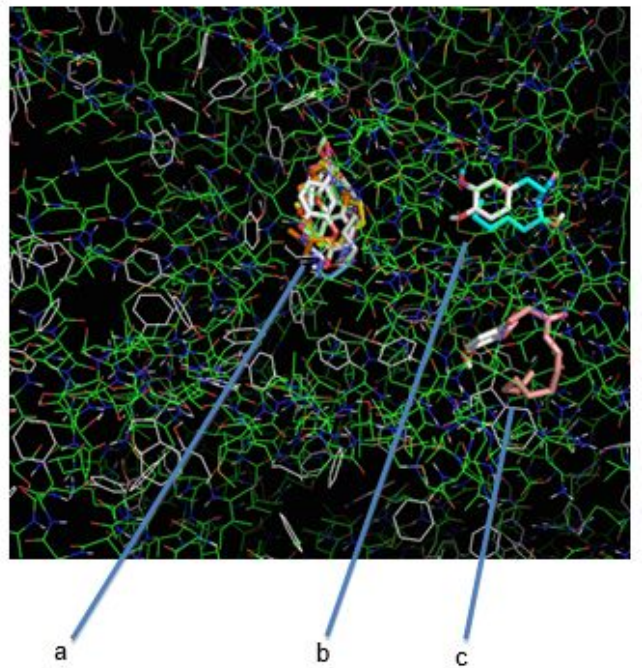

(c)<smiles>CCCCCCCCCC(O)CC(=O)CCc1ccc(O)c(OC)c1</smiles>

(b)

Fig 1. (a) Chemical structures of capsaicin taken by ChemDraw Ultra 12.0.3.1216. A is aromatic, B is amide bond and $\mathrm{C}$ is hydrophobic side-chain; (b) Chemical structures of gingerol and shogaol taken by ChemDraw Ultra 12.0.3.1216; (c) The prediction binding site of gingerol and shogaol in TRPV1 with a: 6-shogaol, 10-shogaol, 8gingerol, 10-gingerol, and capsaicin; b: 6-gingerol; and c: 8-shogaol (ID. 3J9J from rscb.com) 
The capsaicin molecule was divided into three regions i.e. aromatic (A), an amide bond (B), and hydrophobic side-chain (C) (Fig. 1a). The variation of structural composition at $B$ and $C$ region changed the pharmacological activities as previously reported [13]. According to Dedov et al. [13], the activity of gingerol depends on the length of the side chain. Increase number of carbons in gingerol from 6 to 8 , dramatically increased its affinity towards the Vanilloid Receptor 1 (VR1). Another study by Lu et al. [14] found that the antioxidant activity of gingerol and shogaol also depends significantly on their side chain structures such as the $\mathrm{OH}$ at $5^{\text {th }}$ position or double bond at $4^{\text {th }}-5^{\text {th }}$ position. Therefore, further exploration of the side-chain of ginger's active compounds may be profitable in developing more potent compound for controlling pain in PDN via the TRPV1.

The identified bioactive compounds of gingerol and shogaol are 4-gingerol, 6-gingerol, 8-gingerol, 10gingerol, 4-shogaol, 6-shogaol, 8-shogaol, 10-shogaol and 12-shogaol [11]. According to prior reports [14-16], 6-gingerol, 8-gingerol, 10-gingerol, 6-shogaol, 8-shogaol and 10-shogaol have excellent antioxidant activities. Substances with good antioxidant activities may possess other beneficial activities [14]. Therefore, in this study, those 3 active compounds of gingerol and 3 active compounds of shogaol will be tested for their predictive binding energy for TRPV1.

\section{COMPUTATIONAL METHOD}

\section{Ligands Preparation}

The chemical structures of capsaicin as a native ligand, three compounds of gingerol i.e. 6-gingerol, 8- gingerol, 10-gingerol and three compounds of shogaol i.e. 6-shogaol, 8-shogaol, 10-shogaol, as tested ligands, were collected from published literature [1416]. The chemical structures from gingerol and shogaol were shown in Fig. 1b. The two dimensional structures were drawn using ChemDraw Ultra 12.0.3.1216, then the energy minimizations were prepared by Chem3D Ultra to obtain one stable molecular conformation. The structure was saved to .mol2 format [17].

\section{Target Preparation and Validation of Docking Method}

The structure of TRPV1 was taken from Protein Data Bank (rscb.org). The docking analysis was started by finding the binding site on a specific area of the TRPV1. PyMOL programs from www.pymol.org [18], an open source that was distributed by Schrodinger, illustrated the size and location of this binding site. The protein target was validated with AutoDock Vina from vina scripps.edu [18], an open-source software designed by Dr. Oleg Trott [18]. This docking process was based on root mean square deviation (RMSD) value determination. The RMSD value less than $2 \AA$ [17] was used for considering the best docking position between TRPV1 and the ligands.

\section{The Validation of TRPV1 from Protein Data Bank}

The TRPV1 targets were taken from Protein Data Bank (rscb.org) and chosen the TRPV1 that had a ligand. There were three ID of TRPV1 that have been chosen, i.e. 2PNN, 3SUI and 3J9J. From the each of three sources of TRPV1, we validated the position of

Table 1. The validation of TRPV1 as a target receptor using Autodock Tools 1.5.6

\begin{tabular}{|c|c|c|c|c|c|c|c|c|c|}
\hline \multirow{2}{*}{$\begin{array}{l}\text { TRPV1 } \\
\text { code }\end{array}$} & \multicolumn{7}{|c|}{ Position } & \multirow{2}{*}{$\begin{array}{l}\text { The average of binding } \\
\text { energy of capsaicin') }\end{array}$} & \multirow{2}{*}{$\begin{array}{c}\text { The average of } \\
\left.\text { RMSD }^{*}\right)\end{array}$} \\
\hline & size $X$ & size $\mathrm{Y}$ & size Z & center $\mathrm{X}$ & center $\mathrm{Y}$ & center Z & spacing & & \\
\hline \multirow{5}{*}{$2 \mathrm{PNN}$} & 34 & 34 & 34 & 31.532 & -1.016 & -7.652 & 1 & -6.01 & 1.5248 \\
\hline & 32 & 32 & 32 & 31.482 & -0.754 & -8.867 & 1 & -6.13 & 1.8394 \\
\hline & 32 & 32 & 32 & 31.984 & -0.392 & -6.871 & 1 & -6.18 & 1.7532 \\
\hline & 32 & 32 & 32 & 31.728 & 1.312 & -7.629 & 1 & -5.77 & 1.5660 \\
\hline & 32 & 40 & 32 & 31.508 & -0.644 & -8.605 & 1 & -6.10 & 1.9125 \\
\hline \multirow{5}{*}{$3 S U I$} & 22 & 32 & 24 & -9.162 & -18.144 & -12.250 & 1 & -5.30 & 1.8459 \\
\hline & 24 & 32 & 24 & -10.031 & -18.118 & -12.446 & 1 & -5.10 & 1.8765 \\
\hline & 24 & 28 & 28 & -9.638 & -17.444 & -12.894 & 1 & -5.35 & 1.8824 \\
\hline & 24 & 28 & 24 & -10.538 & -18.203 & -12.393 & 1 & -4.61 & 2.016 \\
\hline & 24 & 26 & 26 & -9.162 & -18.144 & -12.250 & 1 & -4.66 & 1.7202 \\
\hline \multirow{5}{*}{ 3J9J } & 34 & 52 & 52 & -8.081 & -19.673 & -17.161 & 1 & -7.14 & 1.9376 \\
\hline & 54 & 36 & 54 & -17.253 & 6.624 & -16.799 & 1 & -7.54 & 2.1416 \\
\hline & 54 & 24 & 54 & 13.755 & -8.656 & -14.254 & 1 & -7.16 & 2.2685 \\
\hline & 24 & 62 & 58 & 9.594 & 17.312 & -15.605 & 1 & -7.05 & 2.2072 \\
\hline & 34 & 48 & 54 & -8.420 & -17.684 & -11.011 & 1 & -7.56 & 1.8969 \\
\hline
\end{tabular}

${ }^{\text {") }}$ the average from ten replication for each position. RMSD is root mean square deviation 
Table 2. The validation of TRPV1 ID.3J9J as a target receptor using Autodock Tools 1.5.6

\begin{tabular}{cccccccccc}
\hline $\begin{array}{c}\text { 3J9J } \\
\text { code } \\
\text { position }\end{array}$ & size $X$ & size $Y$ & size $Z$ & center X & center $Y$ & center Z & spacing & $\begin{array}{c}\text { The average of } \\
\text { binding energy } \\
\text { of capsaicin }\end{array}$ & $\begin{array}{c}\text { The } \\
\text { average of } \\
\text { RMSD }^{*}\end{array}$ \\
\hline & 34 & 52 & 52 & -8.081 & -19.673 & -17.161 & 1 & -7.14 & 1.9376 \\
A & 54 & 36 & 54 & -17.253 & 6.624 & -16.799 & 1 & -7.54 & 2.1416 \\
B & 54 & 24 & 54 & 13.755 & -8.656 & -14.254 & 1 & -7.16 & 2.2685 \\
D & 24 & 62 & 54 & 9.594 & 17.312 & -15.605 & 1 & -7.05 & 2.2072 \\
\hline
\end{tabular}

$\left.{ }^{\star}\right)$ the average from ten replication for each position. RMSD is root mean square deviation

Table 3. The validation of TRPV1 ID.3J9J position A as a target receptor using Autodock Tools 1.5.6

\begin{tabular}{cccccccccc}
\hline $\begin{array}{c}\text { 3J9J for } \\
\text { A } \\
\text { position }\end{array}$ & size $X$ & size $Y$ & size Z & center X & center $Y$ & center Z & spacing & $\begin{array}{c}\text { The average of } \\
\text { binding energy } \\
\text { of capsaicin }\end{array}$ & $\begin{array}{c}\text { The } \\
\text { average of } \\
\text { RMSD }\end{array}$ \\
\hline 1 & 34 & 52 & 52 & -8.081 & -19.673 & -17.161 & 1 & -7.14 & 1.9376 \\
2 & 34 & 52 & 46 & -7.655 & -18.306 & -14.905 & 1 & -7.60 & 1.9809 \\
3 & 34 & 48 & 54 & -8.420 & -17.684 & -11.011 & 1 & -7.56 & 1.8969 \\
4 & 34 & 52 & 52 & -8.081 & -19.673 & -17.161 & 1 & -7.43 & 1.8383 \\
5 & 30 & 50 & 52 & -10.103 & -15.715 & -12.795 & 1 & -7.24 & 2.2737 \\
\hline
\end{tabular}

$\left.{ }^{\star}\right)$ the average from ten replication for each position. RMSD is root mean square deviation

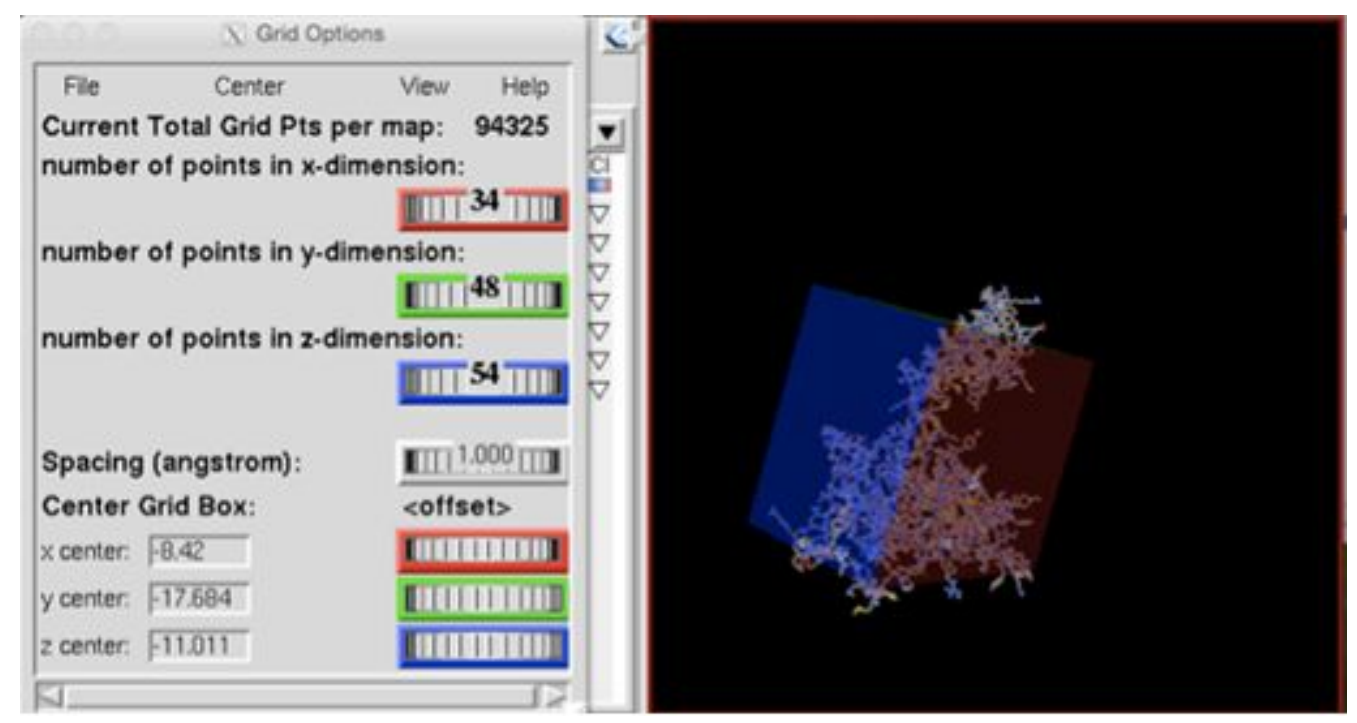

Fig 2. The best docking site on TRPV1 (ID. 3J9J_A3) using Autodock Tools 1.5 .6

capsaicin as the native ligand with the different position in the grid box. For every validation, we needed ten replication and then chosen the best average value of binding energy and RMSD (less than $2 \AA$ ), as seen in Table 1-3.

\section{Molecular Docking Analysis}

Interaction of gingerol and shogaol with TRPV1 were analyzed by AutoDock Vina to describe a possible conformation and orientation for the ligand at its binding site. The protein was drawn in PyRx software (pyrx.sourceforge.net) and protein structure that contain hydrogen in all polar residue was saved in .pdbqt file. In this condition, all bonds of ligands were set to be rotatable. All calculation for protein-fixed ligand-flexible docking were analyzed by the Lamarckian Genetic Algorithm (LGA) method [17]. The docking site on TRPV-1 was defined by establishing a grid box using Autodock tools 1.5 .6 with the best dimensions. After validated, the best of grid box size was $\mathrm{X}$ : $34, \mathrm{Y}: 48, \mathrm{Z}$ : $54 \AA$, with a grid spacing $1.000 \AA$, centered on $X:-8.42$, Y: $-17.684, Z:-11.011 \AA$ as shown in Fig. 2. The best conformation was chosen based on the lowest binding energy after the docking search was completed. Ten runs with AutoDock Vina were performed in all cases of each ligand structure and for each run, the best pose was saved. The average binding energy for best poses was taken as the final binding energy value. This process was repeated three times. PyMOL analyzed the interaction between TRPV1 and ligand conformations, included hydrogen bonds. 
Table 4. The hydrogen bonds between gingerol and shogaol to TRPV1 using PyMOL

\begin{tabular}{lcccccccc}
\hline Compound & Phe 49 & Phe 54 & Phe 58 & Phe 93 & lle 265 & lle 293 & Lys 285 & Gly 210 \\
\hline Capsaicin & + & + & - & - & + & + & - & - \\
6-gingerol & + & - & - & + & - & + & + & - \\
6-shogaol & + & - & - & + & - & + & - & - \\
8-gingerol & + & - & + & + & - & + & + & - \\
8-shogaol & + & - & + & + & - & + & - & - \\
10-gingerol & + & - & + & + & - & + & + & + \\
10-shogaol & + & - & + & + & - & + & - & -
\end{tabular}

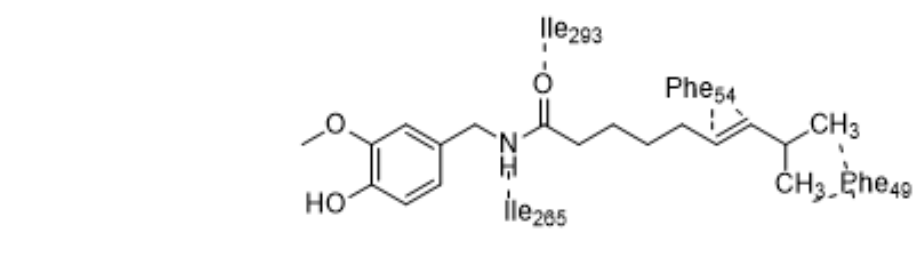

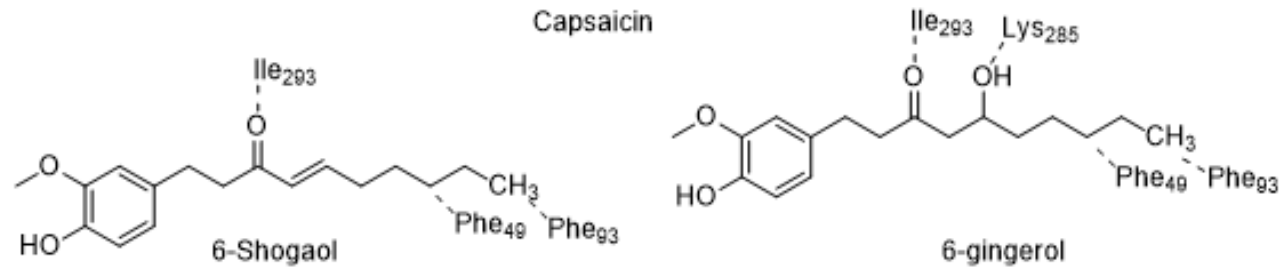

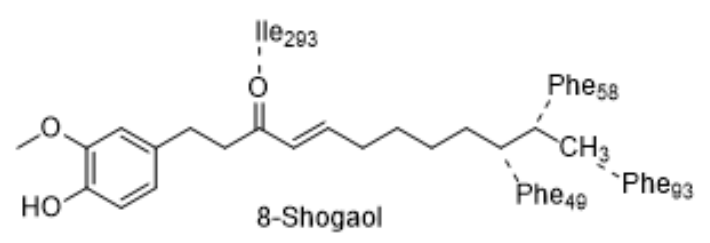

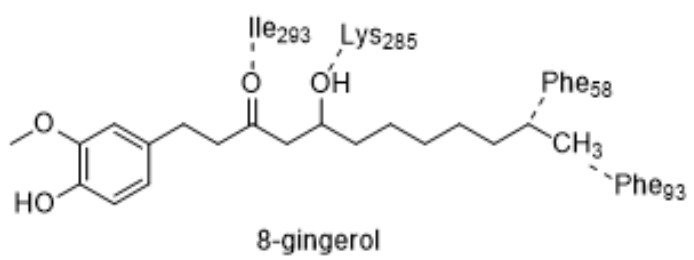

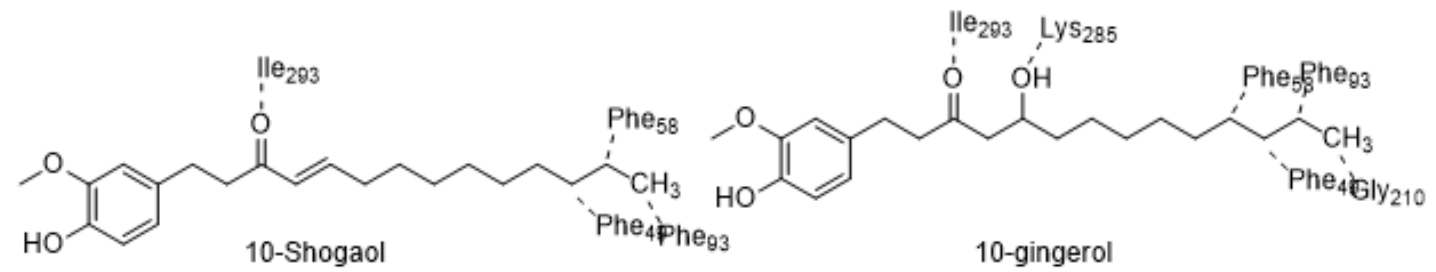

Fig 3. The position of predictive hydrogen bonds between capsaicin, gingerol and shogaol towards TRPV1

\section{Statistical Analysis}

All values of binding energy prediction were presented as mean \pm SEM (standard error of the mean) and statistically analyzed using SPSS ver. 20 (SPSS Inc., Chicago, IL, USA). The binding energy differences between gingerol and shogaol were compared using one-way Analysis of Variate (one-way ANOVA) followed by the Least Significance Difference (LSD) test. Data were considered significant when $p$ values $\leq 0.05$.

\section{RESULT AND DISCUSSION}

The chemical structures of shogaol and gingerol differ in several regions compared to capsaicin. Such variations alter their interaction towards TRPV1 by differences in the position of hydrogen bonds. The 10gingerol has the highest number of hydrogen bonds followed by 8 gingerol i.e. 6 and 5 bonds, respectively (Table 4). The capsaicin only has 4 bonds as well as other tested compounds, except for 6 shogaol that only has 3 bonds. All of the tested compounds bind to Phe49 and lle293 of TRPV1.

All of the ginger's tested compound lack the binding to Phe54 and Ile265, to which capsaicin is bound. The previous study showed that the substitution of amide in capsaicin increased its hydrophobicity and potency higher than both gingerol and shogaol [15]. Based on Fig. 3, the amide group of capsaicin forms hydrogen bond at position Ile265. All of shogaol and 
Table 5. Validation and binding energy prediction of gingerol and shogaol to TRPV1 (3J9J) using AutoDock Vina

\begin{tabular}{|c|c|c|c|c|c|c|c|c|}
\hline \multirow{2}{*}{ Ligand } & \multicolumn{3}{|c|}{$\begin{array}{l}\text { RMSD } \\
\text { replication- }\end{array}$} & \multicolumn{3}{|c|}{$\begin{array}{l}\text { Binding Energy (kcal/mol) } \\
\text { replication- }\end{array}$} & \multicolumn{2}{|c|}{ Mean \pm SEM } \\
\hline & 1 & 2 & 3 & 1 & 2 & 3 & RMSD & $\begin{array}{l}\text { Binding energy } \\
(\mathrm{kcal} / \mathrm{mol})\end{array}$ \\
\hline Capsaicin & 1.90 & 1.85 & 1.80 & -7.56 & -7.20 & -7.32 & $1.85 \pm 0.05$ & $-7.36 \pm 0.11^{a}$ \\
\hline 6-shogaol & 1.61 & 1.63 & 1.68 & -6.98 & -7.18 & -7.13 & $1.64 \pm 0.04$ & $-7.10 \pm 0.06^{a}$ \\
\hline 8-shogaol & 1.59 & 1.60 & 1.60 & -6.47 & -6.57 & -6.46 & $1.60 \pm 0.01$ & $-6.50 \pm 0.04^{b}$ \\
\hline 10-shogaol & 1.64 & 1.75 & 1.62 & -6.50 & -6.65 & -6.33 & $1.67 \pm 0.07$ & $-6.49 \pm 0.09^{b}$ \\
\hline 6-gingerol & 1.76 & 1.64 & 1.73 & -6.48 & -6.43 & -6.40 & $1.71 \pm 0.06$ & $-6.44 \pm 0.02^{b}$ \\
\hline 8-gingerol & 1.74 & 1.81 & 1.73 & -6.94 & -6.78 & -7.05 & $1.76 \pm 0.04$ & $-6.92 \pm 0.08^{a}$ \\
\hline 10-gingerol & 1.84 & 1.77 & 1.69 & -6.34 & -6.37 & -6.55 & $1.76 \pm 0.08$ & $-6.42 \pm 0.07^{b}$ \\
\hline
\end{tabular}

Negative (-) notation showed that energy for binding between ligand and receptor was lower. RMSD is root mean square deviation. a is significantly different versus $\mathrm{b}$ (one way ANOVA ; $p<0.05$ )

Table 6. In-vitro activity from derivates of gingerol and shogaol

\begin{tabular}{|c|c|c|c|c|c|c|}
\hline Compound & $\begin{array}{l}\mathrm{IC}_{50} \text { free radical } \\
\text { scavenging }(\mu \mathrm{M})^{* 1}\end{array}$ & $\begin{array}{c}I_{50} \text { ROS } \\
(\mu \mathrm{M})^{* 2}\end{array}$ & $\begin{array}{c}\text { nitrit release } \\
(\%)^{* 3}\end{array}$ & $\begin{array}{c}\mathrm{PGE}_{2} \\
\text { release }(\%)^{*}\end{array}$ & $\begin{array}{c}\text { TRPV1 } \\
\text { (efficacy) }^{*} \text { 作 }\end{array}$ & $\begin{array}{c}\text { FRAP } \\
\text { assay }(\mathrm{ne})^{* 6}\end{array}$ \\
\hline Capsaicin & nd & nd & nd & nd & $78.6 \pm 2.4$ & nd \\
\hline $\begin{array}{l}\text { 6-shogaol } \\
\text { 8-shogaol }\end{array}$ & $\underset{\text { nd }}{8.05 \pm 1.02}$ & $\begin{array}{c}0.85 \\
\text { nd }\end{array}$ & $\begin{array}{l}80 \\
\text { nd }\end{array}$ & $\begin{array}{l}87 \\
\text { nd }\end{array}$ & $\underset{\text { nd }}{79.2 \pm 0.9}$ & $\underset{\text { nd }}{2.81 \pm 0.01}$ \\
\hline 10-shogaol & nd & nd & nd & nd & nd & nd \\
\hline 6-gingerol & $\underset{\text { nd }}{26.3 \pm 1.42}$ & 4.05 & 45 & 58 & $\underset{\text { nd }}{51.3 \pm 1.7}$ & $\underset{\mathrm{nd}}{2.39 \pm 0.04}$ \\
\hline 10-gingerol & nd & 1.68 & 75 & 73 & nd & nd \\
\hline
\end{tabular}

${ }^{{ }^{*} 1}$ relative scavenging potential by investigating free radical using DPPH [16]

${ }^{*}$ ROS scavenging potential [16]

${ }^{* 3}$ inhibition of NO production in LPS-stimulated RAW 264.7 cells [16]

${ }^{*}$ inhibition of PGE2 formation in LPS-stimulated RAW 264.7 cells [16]

${ }^{*}$ as percentage of ionomycin $4 \mu \mathrm{M}[15]$

${ }^{* 6}$ Antioxidant activity using FRAP ([14]

nd means no data

gingerol compounds lack the hydrogen bond at position lle265 due to the lack of the amide group in gingerol and shogaol. Therefore, the lle265 binding is unique for capsaicin and may be the crucial site of its TRPV1 binding.

All of the gingerols and shogaols have Phe93 bonds, instead. The hydrogen bonds of ginger's active compounds to TRPV1's Phe58 are due to the addition of carbon-side chains in 8-shogaol, 8-gingerol, 10-shogaol and 10-gingerol. Therefore, 6 gingerol and 6 shogaol lack the Phe58 hydrogen bond. The gingerols also have Lys285 binding capacity due to the hydroxyl groups in region "B" of gingerol. This bond does not exist in shogaol and it is due to the replacement of the hydroxyl $(-\mathrm{OH})$ groups in $5^{\text {th }}$ position in gingerol with a double bond $(C=C)$. Whereas, the elongation of carbon-side chains in 10-gingerol form hydrogen bond at Gly210 that is not seen in 10-shogaol.

According to analysis of predicted binding energy (shown in Table 5), the gingerol and shogaol compounds bind to TRPV1 with varied affinity. Binding energy indicates the affinity value of ligand bond into the receptor. The binding energy value is related to the amount of energy that is required by the ligand to bind to a receptor. The less the binding energy (more negative value), the more stable the bond between ligand and receptor. Among the six compounds tested, 6-shogaol has the lowest binding energy $(-7.10 \mathrm{kcal} / \mathrm{mol})$. This value is not significantly different with the binding energy of capsaicin $(-7.36 \mathrm{kcal} / \mathrm{mol})$; 10 -gingerol also has binding energy that is not statistically different with 6 -shogaol and capsaicin. However, 10-shogaol binding energy $(-6.98 \mathrm{kcal} / \mathrm{mol})$ is slightly higher than 6shogaol's binding energy. Substitution of an amide in capsaicin appears to increase its lipophilicity and causes higher potency than gingerol.

The other compounds have weaker binding energy prediction than 6-shogaol and 10-gingerol. The binding energy of 8-shogaol and 10-shogaol, -6.50 $\mathrm{kcal} / \mathrm{mol}$ and $-6.49 \mathrm{kcal} / \mathrm{mol}$ consecutively, are weaker than 6-shogaol $(-7.10 \mathrm{kcal} / \mathrm{mol})$, which indicate that elongation of carbon chain in shogaol reduce the affinity between shogaol and TRPV1. On the other hand, 8-gingerol has the stronger binding energy (-6.92 $\mathrm{kcal} / \mathrm{mol})$ than 10-gingerol $(-6.42 \mathrm{kcal} / \mathrm{mol})$. The differences of chemical structures between gingerol and shogaol, alter the hydrogen bonds, and their affinity toward TRPV1.

There were much previous research (Table 6) that have been done to compare the antioxidant and antiinflammatory activity of derivates of gingerol and shogaol by in vitro models. Their results also showed 
that 6-shogaol had the most potent activity compared to the other derivates. It can be concluded that the in vitro results supported the docking results.

\section{CONCLUSION}

According to our result, 6-shogaol has the best binding energy toward TRPV-1, comparable to capsaicin. Therefore, further study is needed to evaluate the activity of 6 -shogaol in preventing PDN.

\section{REFERENCES}

[1] Alleman, C.J.M., Westerhout, K.Y., Hensen, M., Chambers, C., Stoker, M., Long, S., and van Nooten, F.E., 2015, Humanistic and economic burden of painful diabetic peripheral neuropathy in Europe: A review of the literature, Diabetes Res. Clin. Pract., 109 (2), 215-225.

[2] Whiting, D.R., Guariguata, L., Weil, C., and Shaw, J., 2011, IDF diabetes atlas: Global estimates of the prevalence of diabetes for 2011 and 2030, Diabetes Res. Clin. Pract., 94 (3), 311-321.

[3] Shaw, J.E., Sicree, R.A., and Zimmet, P.Z., 2010, Global estimates of the prevalence of diabetes for 2010 and 2030, Diabetes Res. Clin. Pract., 87 (7), 4-14.

[4] Hartemann, A., Attal, N., Bouhassira, D., Dumont, I., Gin, H., Jeanne, S., Said, G., and Richard, J.L., 2011, Painful diabetic neuropathy: Diagnosis and management, Diabetes Metab., 37 (5), 377-388.

[5] Pabbidi, R.M., Yu, S.Q., Peng, S., Khardori, R., Pauza, M.E., and Premkumar, L.S., 2008, Influence of TRPV1 on diabetes-induced alterations in thermal pain sensitivity, Mol. Pain, 4 (9).

[6] Luongo, L., Costa, B., D'Agostino, B., Guida, F., Comelli, F., Gatta, L., Matteis, M., Sullo, N., De Petrocellis, L., de Novellis, V., Maione, S., and Di Marzo, V., 2012, Palvanil, a non-pungent capsaicin analogue, inhibits inflammatory and neuropathic pain with little effects on bronchopulmonary function and body temperature, Pharmacol. Res., 66 (3), 243-250.

[7] Zhuo, M., 2013, Long-term potentiation in the anterior cingulate cortex and chronic pain, Philos. Trans. R. Soc. London, Ser. B, 369, 20130146.

[8] Haanpää, M., and Hietaharju, A., 2015, Halting the march of painful diabetic neuropathy, Pain Clin. Updates, 23 (2), 1-8.
[9] Brito, R., Sheth, S., Mukherjea, D., Rybak, L.P., and Ramkumar, V., 2014, TRPV1: A potential drug target for treating various diseases, Cells, 3 (3), 517-545.

[10] Shaqura, M., Khalefa, B.I., Shakibaei, M., Zöllner, C., Al-Khrasani, M., Fürst, S., Schäfer, M., and Mousa, S.A., 2014, New insights into mechanisms of opioid inhibitory effects on capsaicin-induced TRPV1 activity during painful diabetic neuropathy, Neuropharmacology, 85, 142-150.

[11] Chrubasik, S., Pittler, M.H., and Roufogalis, B.D., 2005, Zingiberis rhizoma: A comprehensive review on the ginger effect and efficacy profiles, Phytomedicine, 12 (9), 684-701.

[12] Semwal, R.B., Semwal, D.K., Combrinck, S., and Viljoen, A.M., 2015, Gingerols and shogaols: Important nutraceutical principles from ginger, Phytochemistry, 117, 554-568.

[13] Dedov, V.N., Tran, V.H., Duke, C.C., Connor, M., Christie, M.J., Mandadi, S., and Roufogalis, B.D., 2002, Gingerols: A novel class of vanilloid receptor (VR1) agonists, Br. J. Pharmacol., 137 (137), 793798.

[14] Lu, D.L., Li, X.Z., Dai, F., Kang, Y.F., Li, Y., Ma, M.M., Ren, X.R., Du, G.W., Jin, X.L., and Zhou, B., 2014 , Influence of side chain structure changes on antioxidant potency of the [6]-gingerol related compounds, Food Chem., 165, 191-197.

[15] Morera, E., De Petrocellis, L., Morera, L., Moriello, A.S., Nalli, M., Di Marzo, V., and Ortar, G., 2012, Synthesis and biological evaluation of [6]-gingerol analogues as transient receptor potential channel TRPV1 and TRPA1 modulators, Bioorg. Med. Chem. Lett., 22 (4), 1674-1677.

[16] Dugasani, S., Pichika, M.R., Nadarajah, V.D., Balijepalli, M.K., Tandra, S., and Korlakunta, J.N., 2010, Comparative antioxidant and antiinflammatory effects of [6]-gingerol, [8]-gingerol, [10]-gingerol and [6]-shogaol, J. Ethnopharmacol., 127 (2), 515-520.

[17] Herowati, R., and Widodo, G.P., 2014, Molecular docking studies of chemical constituents of Tinospora cordofolia on glycogen phosphorylase, Procedia Chem., 13, 63-68.

[18] Trott, O.A., and Olson, J., 2011, Autodock Vina: Improving the speed and accuracy of docking with a new scoring function, efficient optimization and multithreading, J. Comput. Chem., 31 (2), 455461. 